\title{
Women, Livelihood and Oil and Gas Discovery in Ghana: An exploratory Study of Cape Three Points and Surrounding Communities
}

\author{
Rosemond Boohene (PhD) (Corresponding author) \\ School of Business, University of Cape Coast \\ Cape Coast, Ghana \\ E-mail: rboohene@yahoo.com \\ James Atta Peprah \\ Department of Economics, University of Cape Coast \\ Cape Coast, Ghana \\ E-mail: peprahjames@rocketmail.com
}

Received: February 17, 2011

Accepted: April 28, 2011

doi:10.5539/jsd.v4n3p185

\begin{abstract}
The role of oil and gas exploration and other natural resources in the economic development of a country cannot be over emphasized. Unfortunately, in most oil producing countries women have not benefited from oil and gas exploration. This study therefore seeks to explore the effects of the oil find in Ghana on the livelihood of women in the catchment area of Cape Three Points. Purposive sampling was used to select two hundred and forty respondents who were interviewed in two communities at Cape Three Points about their anticipated challenges and prospects in the wake of the oil find. Results indicate that more than half of the respondents perceive a decrease in fish catch, loss of jobs for husbands and reduction in income levels. It is recommended that in order for women to take advantage of the oil find, there is the need to create alternative livelihoods such as access to finance; capacity building; training and development; and technical services for women in the catchment area.
\end{abstract}

Keywords: Women, Oil and gas, Livelihoods

\section{Introduction}

Oil nicknamed "the black gold", stimulates the global economy and converted into petrol and diesel fuels facilitate the different means of transportation that allows for the movement of goods and people around the globe (Darkwa 2010). Due to the huge financial resources that can accrue from this industry, its role in a country's economic development cannot be over emphasized. Oil does not only serve as a major foreign exchange earner for a nation but also creates employment avenues for both men and women.

Ghana has a modest upstream oil industry with one onshore and five offshore sedimentary basins. The main drive behind the oil and gas industry in Ghana is the need to reduce the country's dependence and reliance on hydroelectricity. On February 19, 2009, International Finance Corporation (IFC) Board of Directors authorized Ghana to enter into investment agreements to support the development of Ghana's Jubilee field, an offshore oil and gas project that will help to diversify Ghana's economy and satisfy her energy needs. The project, located in deep water some 60 kilometers off the coast of Ghana, will produce crude oil, generating foreign exchange income for the country and substituting expenditures for oil imports. It will also boost government revenues against the background of the current global economic downturn that may have negative effects on developing countries for years to come. In addition to the proposed \$100 million loan to Kosmos Energy and \$115 million loan to Tullow Oil, IFC will assist the companies in enhancing the project's benefits for local communities. Ghana's share as represented by the Ghana National Petroleum Corporation (GNPC) is 13.75\%.

An important aspect to note is that the downstream oil industry is crucial to the Ghanaian economy. This is because oil-derived products supply about $70 \%$ of Ghana's commercial energy needs. The current consumption of petroleum products is in the region of 950,000 tons per annum. Increasing power demands by industry and domestic consumption and a need to reduce the reliance on hydroelectric power is not only fuelling the search 
for oil and gas but also has set in motion projects relating to the importation of gas via pipeline from Nigeria and La Cote d'Ivoire. The prospect of Ghana becoming a net exporter of oil and having its own natural gas production has raised many issues and concerns, including sector governance issues such as revenue managing expectations, developing capacity of technocrats at various government agencies, educating the public and civil society organizations, and avoiding revenue management challenges through transparency.

The Ghana Living Standards Survey (GLSS 5) (GSS, 2008) estimates that women constitute about $51.4 \%$ of the entire population. Majority of these women are engaged in microenterprises basically petty trading, craft work, menial jobs and farming with unsecured sources of income. The inadequacy of effective policy guidelines to protect citizens from oil and gas exploitation, in various parts of the continent, have resulted in social conflicts and deep-rooted poverty in oil producing areas and widened gaps between the rich and the poor and also deepened inequalities between various social groups including women. Thus the discovery of oil and gas in the Western region specifically Cape Three Points and its environs means that women livelihoods are going to be affected. For example, currently fishermen in Sekondi, a twin city of Takoradi have been cautioned not to fish in the areas of the oil rig where fishes usually dominate. This will displace most fishermen and fish mongers as well as dependants of fishermen in the oil and gas areas. The Ghana government has outlined policies that will promote economic development and local participation of Ghanaians in the oil industry, but Ghanaian policy makers have not yet specified what specific roles women are going to play to contribute to the expected economic development. In addition, various Non-Governmental Organisations have conducted a base line study on the effect of the oil industry on women without proposing any alternative livelihoods for them. This exploratory research therefore seeks to fill that gap and examines the effects of the oil and gas exploration on the livelihoods of women in the Cape Three Points area.

The rest of the paper is presented as follows: the next section reviews related literature on the oil and gas industry, followed by the methodology in the third section. Sections four and five examine the results and discussion and conclusions and recommendations respectively.

\section{Literature Review}

The development economics literature prior to the late 1980s is often referred to for its claims that natural resources are good ingredients for development. However, later research (Tadjoeddin, 2007) demonstrated that rich natural resource endowments are more likely to result in a curse - rather than a blessing in the form of negative development outcomes including poor economic performance, non-democracy and civil war. In another development, Sachs and Warner (1995) demonstrated empirically that the 'curse' of natural resource ownership was substantial. They showed that economic growth was inversely related to various measures of resource abundance. Their results showed that between 1965-1998, Gross National Product per capita growth in the Oil and Petroleum Exporting Countries (OPEC) decreased on average by 1.3 percent, while in the rest of the developing world, per capita growth was on average 2.2 percent. Apart from oil and gas resources other natural resources such as land have also not contributed positively to economic development in some cases. For example, Galor, Moav and Vollrath (2009) researched into the link between land inequality and economic development. They revealed that land inequality is negatively related to the point of time in which landowners support public education conducive to growth. Galor, Moav and Vollrath (2009) in their model showed that landowners would eventually be in favor of mass education (because they own the bulk of the capital stock and there are capital-skill complementarities). Again, Falkinger and Grossmann (2005) proposed a theory in which the opposition of the landed elite to mass education is related to openness to trade, where an open trade regime is politically supported by the landed elite under a comparative advantage for primary goods production. However, this model does not explain the emergence of an entrepreneurial class with different interests than the traditional elite.

The oil boom in some countries has witnessed active women participation in the economic sector even though some countries have witnessed negative consequences. The implication is that oil production affects gender relations by reducing the presence of women in the labour force. There is therefore the need for alternative livelihood activities to support women who might not be engaged in the oil and gas activities. It is usually argued that in the oil and gas industry men dominate whereas women are relegated to the background. One possible reason is that, women do not usually have the know-how to work in the oil and gas industry. Thus, the pauperization of the women folk by the seemingly harsh and male dominated economic sphere coupled with the maximization of profits by the corporate world without the consideration for the basic and the welfare needs of the masses especially women (Elson \& Pearson, 1997) have the potential to further reduce the ability and capacity of the women folk to equal opportunities to wealth creation and decent living standards. 
In a recent study, titled Oil, Islam and Women, Ross (2008) made some interesting claims regarding the relationship between an oil-based economy and gender equality. Simply put, an export directed oil-based economy shuts women out of the workforce consequently lowering their capacity for political influence and rendering them economically incapacitated. Ross's (2008) argument goes against several commonly upheld theories regarding economic development and gender equality. Inglehart and Norris (2003) suggested that, economic development automatically leads to an improvement in gender equity. Other studies have suggested that this principle does not hold true for oil-rich Gulf States because of the patriarchal structures of Muslim countries where women are suppressed. Ross argues that when a developing country suddenly experiences an oil boom, the demand for locally produced goods diminishes and is diverted toward non-tradable goods such as construction and heavy industry. Given the occupational segregation of labour present in most developing societies, women are consequently shut out of jobs for two reasons. One, the rising male income makes women's' jobs superfluous in terms of economic contribution; and two, because the light industry jobs attracting women to the labour force are eliminated.

In South Korea, as indicated by Ross (2008), the new demand for manufacturing garments, electronics and plastic goods for export was high as a result of industrialization which changed the position of women in the 1960s. The purveyors of these industries sought out young unmarried women for jobs because they proved to be good workers, and also because the physical demands of these jobs did not require men. In a similar vein, can the oil and gas exploration change the status of women in Ghana? The answer is that even if women are not employed in the oil industry there are still some opportunities for them to undertake economic activities abandoned by men to make livelihoods. With the incorporation of women into the alternative workforce, similarly, women were provided a platform where they could interact and organize, with the consequent emergence of women's groups that worked for more rights, better education and more legal equality for women. The South Korean case illustrates how industrialization and the entry of women into non-agricultural jobs can pave the way for gender equality, economic empowerment and livelihood sustainability in the wake of oil and gas production.

Another argument proffered by Ross (2008) is that, as a result of oil boom women have fewer incentives to enter the alternative workforce; immigrant labour can pay women to offer them services which they (the immigrant labour) cannot have time to carry out as a result of their heavy involvement in the oil fields. The result, proven by Ross's (2008) statistical correlation of oil rents and lack of gender representation, is that the most oil-rich countries - specifically Oman, Saudi Arabia, Qatar and the United Arab Emirates - have the fewest women in their workforce, are the most reluctant to grant women the vote, are least likely to give them representation in parliament and score the lowest on the gender development index (GDI). In such situations, if women are not provided with livelihood activities, then, the oil boom has served to drive women out of the workforce. This may lead to an increase in fertility and illiteracy rates, a stagnation of the level of political participation as well as economic incapacitation.

According to Omorodion (2004) oil workers and local men use the income generated from oil to purchase female sexuality in terms of sexual partners. In Nigeria's Niger Delta fieldwork showed that men married more wives, kept more concubines and maintains the loyalty of females from or outside the indigenous population. Furthermore, the high income received by men and the payments given to men for no work done, encouraged 'co-modification' of women that resulted to modern slavery, as women were seen in terms of their sex and the sexual services they rendered to the men. Women were objectified, thus bought as commodities and used at the discretion of men, who can afford to purchase their sexual services.

Oil and gas find however, do not only come with problems but also lots of opportunities. Oil and gas production come with other supporting economic activities such as hotel and restaurant services, banking, transport activities, health care services, road construction, telecommunication, and many more allied services that are able to benefit the people. It must be emphasized that these services are realized only when the oil resources are well managed. What advantage can the poor, especially women, take advantage of and with what resources? The livelihood framework demands that people are equipped with livelihood assets. The use of these assets is influenced by policies, institutions and processes in order to produce outcomes.

In addition, oil and gas drilling at the gulf brings along it exciting tourist attractions. For example at the gulf of Mexico more than 120 decommissioned oil rigs in the gulf have been converted into submerged artificial reefs in the industry's "rigs-to-reefs" program. These reefs have been providing living and feeding habitats for thousands of underwater species, enhancing the ecosystem of the entire Gulf and promoting tourism for the fishing diving industries (http://www.api.org/policy/exploration/upload/070319_Environmental_Harmony_Offshore.pdf). 
In some cases, gourmet mussels and other succulent shellfish which are harvested from the legs of these offshore platforms are served in many of the finest seafood restaurants. Moreover, butterflies and birds use the oil gulf platforms as resting places during their annual migration which serve as tourist attraction. In the case of Ghana such opportunities when materialized can offer employment to displaced fishermen and unemployed women in the catchment area, Western Region and the country as a whole.

Majority of women in Ghana engage in farming activities basically the cultivation of staple crops such as cassava, plantain, maize, yam and vegetables. It has been established that oil and gas exploration activities especially in-shore drilling negatively affect the production of such crops (Odeman, n.d.). For example, in the Niger Delta communities in Nigeria, one of the most important crops grown by women is cassava. Gas flaring, which is a continuous exercise in the Niger Delta communities, has been implicated in suppression of plant growth near the flaring points. Imevbore and Adeyemi (1981) said there is a decrease in length, weight, starch, protein and ascorbic acid (Vitamin C) content of cassava around the flaring points. Also, acid rain in the region, which could be partly attributed to gas flaring, leads to acidity of the soil (loss of soil fertility) and damaged crops (Gabriel, 2004). This has contributed to a fall in cassava production in the region thus affecting the income levels of these women engaged farming activities. These in the short and long-term make women economically disadvantaged and hence deepen the poverty status of affected women (Figure 1 shows the impact of oil and gas on women).

\section{$=$ INSERT FIGURE $1=$}

The key questions therefore posed by this study are: (1) what are the likely effects of the discovery on women economic activities? (2) Are there any opportunities for women entrepreneurs in the oil and gas mining communities? (3) What are the possible livelihood strategies for these groups?

\section{Methodology}

\subsection{The study area}

The Western region with a population of $1,924,577$ is made up of 978,176 females and 946,401 males. In the region about $36.3 \%$ of the population live in the urban centres whereas $63.7 \%$ dwell in rural areas.

Western Region is the largest producer of cocoa, rubber and coconut and one of the major producers of palm oil, with agriculture accounting for $58.1 \%$ of employment in the region. The region's rich forest resources also make it one of the largest producers of timber and wood based products. The region also has the highest concentration of individual gold mines in the country, while the nation's active bauxite and manganese mines are to be found entirely within the Western Region. In spite of these blessings, it seems the region has not benefited much from its share of the natural resources.

Cape Three Points (Akyinkyin) ${ }^{1}$ is a small peninsula in the Ahanta West District of the Western region where Ghana has made the oil and natural gas discovery. Forming the southernmost tip of Ghana, it is located between the coastal towns of Dixcove and Princes Town. Cape Three Points is known as the "land nearest nowhere" because it is the land nearest a location in the sea which is at 0 latitude, 0 longitude and 0 altitude (the distance is about $570 \mathrm{~km}$ ). It is best known for its lighthouses, the first of which was constructed in 1875 by the British as a navigational aid for trading vessels sailing through the Gulf of Guinea. It is a small fishing community but popularly known for being the Western Cape along the shores of the country. Some communities close to Cape Three Points are Princes Akatakyi, Akwalaa and Light House. The main occupation of the people in these communities is fishing. Women engage in the production of staple crops such as cassava, maize, yam and other vegetables for subsistence consumption. A number of women are also fish mongers who buy fish from the shore, smoke them and sell them to middle-women. In some few cases one would find some fisherwomen who go to sea but this practice is not common even though it is also not a taboo. The communities closer to the oil and gas exploration areas have limited social amenities. For example a visit to the communities revealed that the roads are in bad state, there is no portable water for the people, and no hospital. According to the people they were expecting that road construction for example should be part of the exploration because big trucks have started plying the road during the exploration process.

\subsection{Population and sample}

The population of the study comprised all women who are domiciled in the various communities around the Cape Three Points area. They were chosen because they will directly be affected by the oil and gas exploration activities. The purposive sampling method was employed to select the women who were traders, farmers and fishmongers involved in fish related activity or are married to fishermen. In all 240 adult women were selected 
from the targeted communities to find out their perceptions about the possible challenges and prospects of the oil and gas production activities in the area.

\subsection{Data collection methods and analytical techniques}

Structured questionnaires were designed to solicit opinion from targeted women in the study area. Level 300 Economics students from the Department of Economics collected the data. Research Assistants were engaged to supervise the administration of the questionnaire in the local dialect since most of the women could not read and understand the questions themselves. For the purposes of data validation, twenty questionnaires were pilot-tested and analysed. The results informed us to re-structure the final questionnaire. The questionnaires were then administered in November, 2010 which was one month ahead of the actual production of the oil.

The data was tabulated and entered into the Statistical Package for Social Science (SPSS) software for analysis. Data was properly cleaned to avoid inconsistency in the responses provided. Descriptive analysis was used to analyze the current sources of livelihoods, loss of expected revenues, likely opportunities and the resources required to take advantage of the oil and gas exploration.

\section{Results and Discussion}

A preliminary analysis using secondary data was conducted to examine the characteristics of people who live in Cape Three Points and its catchment area. This is depicted in Table 1. The table shows that there were more females $(52.3 \%)$ in the district than males $(43.7 \%)$. The female proportion was about $1 \%$ higher than the national average. In addition, majority of the population are females who fall within the 15-64 age groups. These calls for more relevant policies that will address women concerns majority of whom are domiciled in the district and who will also be affected the oil find.

\section{$=$ INSERT TABLE $1=$}

\subsection{Effects of oil exploration on women economic activities}

The first research question sought to find out the effects of the discovery of oil and gas on women economic activities. The results are presented in Table 2. From the table the greatest effect is perceived to be low fish catch and the least, cultural change. More than half of the respondents $(52.0 \%)$ are of the view that fish catch will fall, there will also be loss of jobs and income levels will fall in like manner.

$=$ INSERT TABLE $2=$

Pollution through various oil and gas activities is rife, and will lead to chemical pollution of water bodies, air and noise, as well as plant pollution. Coconut grown along the shores is likely to suffer from absorption of poisonous substances that will affect the process of photosynthesis. This will undoubtedly affect the health status of the populace in these communities because for some coconut is consumed on a larger scale. Not only coconut will be affected, but it is also likely that crops grown along the sea are likely to suffer from similar biological effects.

The results of the baseline study depicted in Table 2 indicate that 27.9 percent of the respondents asserted that the oil discovery would bring about great loss in the quantity of fish. Even though the percentage is quite marginal, it still confirms the assertion that fish catch will reduce. The fall in the fish catch may not be attributed to the restriction imposed by naval officials as claimed by some women but also in case of oil spillage, the impact on aquatic creature will be great. In a recent publication by the Daily Graphic, some fisher folks in Sekondi-Takoradi Metropolis protested against the order issued by the naval officers in charge of the rig protection. They also complained about the persistent harassment by the officers which they see as threat to lives and denial of source of livelihood.

According to a section of the residents, the drilling of oil is likely to cause a loss of income as can be seen from Table 3. For example the average income women are likely to lose falls between 201 and 500 Ghana cedis monthly, whereas maximum and minimum loss of income from fish and other related activities are more than 1000 Ghana cedis but less than 100 Ghana cedis respectively. Fish activities include fishing, fish processing (smoking and salting) and fish mongering.

\section{$=$ INSERT TABLE $3=$}

Moreover, women around Cape Three Points and its surrounding communities (1.7\%), indicated that it will not be in the interest of the gods of the sea if oil is drilled everyday of the week. They believe that this will affect fishing since they will find it difficult to offer the sacrifices, which they usually offer on Tuesdays ${ }^{2}$ to the gods of the sea. 
Majority of respondents (29.7\%) are not aware of how much they are likely to lose as a result of the oil and gas drilling. This is not surprising because most people in the informal sector do not keep records of their income and expenditure. Cumulatively $70.3 \%$ of respondents are likely to lose income range from 100 to more than 1000 Ghana cedis monthly.

Since the exploration started in the area, women have been engaging in other livelihood activities popular among them is farming $(68.8 \%)$. It is interesting to note that $10 \%$ of respondents do not have any other source of livelihood. The question is how do they survive as caretakers of the home? Petty trading has not been a popular economic activity in the area probably because of access to credit. Fish catch is dwindling as a result of the oil exploration. Trading activities which are basically fish selling, have also been affected. Artisanal work includes mat weaving, basketry and pottery. Some women (6.2\%) claim they are now learning how to use the coconut branches and leaves to weave mat and basket to earn a living. Food processing also includes extraction of coconut oil, fish smoking and salting. It is observed that only a few women $(2.1 \%)$ are engaged in this activity because of low fish catch. Some women also claim they have to travel to nearby mining villages to join their husbands in 'galamsey' (illegal mining) business.

\subsection{Oil and gas discovery in Ghana: Any opportunities for women?}

Research evidence from the global context shows that women have little opportunities in oil and gas industry. The usual reason has been the low level of education and skills required for industry. Where they possess the requisite skills, women are considered to be caretakers of the home which makes it very difficult for them to engage in the employment of such activities. Oil production has been described as a very masculine job which most women seem not have the capacity to engage in. This notwithstanding, most women in the area believe that oil discovery will offer them some indirect opportunities. For example they are of the view that the activity will boost sales, create job opportunities for their husbands, and increase their children's school enrolment as they expect financial assistance for their children. It is not doubtful to hope that sales will be boosted. Economic signals in Sekondi-Takoradi Township show that prices of goods and services have started escalating. This gives greater opportunity for women in trading. What women need is financial assistance to expand their trading activities. Economically, one can argue that loss of income from fish activities would be compensated by increase in income from trading activities, all other things being equal.

If it is assumed that industrialisation brings along development through localization of firms as economic theory posits, then we should expect the concentration of service activities in the area. Such activities include hotel businesses, banking, insurance, telecommunication, and a lot more. Women with the required educational background will be gainfully employed in such businesses. Also majority of women who might not have the requisite education background could be engaged in the manual jobs that are available in these businesses. Whether these expectations will be fulfilled or not depends upon what actually happens during the production and post-production stages. In spite of these expectations there is still the need to propose some alternative livelihood projects for our women.

\subsection{Alternative Livelihood Projects (ALPs): A proposition}

The government has reiterated her commitment to the provision of alternative livelihood for local people to reduce pressure on lands adjacent to protected areas and water bodies as enshrined in the Ghana Shared Growth and Development Agenda (GSGDA) 2010-2013. In this respect, there is the need to formulate appropriate alternative livelihood projects (ALPs) also known as Local Economic Development projects (LED) to ensure sustainable growth that will contribute to up-scaling poverty reduction.

It is well known fact that women participation in the oil and gas industry is likely to be low because most women lack the know-how. Thus, expectations of Ghanaian women are not different from experiences of other developed and developing countries. For example women have low representation in oil and gas industry in Canada (Sherk, 2004), Pakistan, South Korea (Ross, 2008), and Nigeria's Niger Delta (Omorodion, 2004) just to mention a few. The challenges outlined in table 1 have consequences for vulnerability. There is likely to be food insecurity in the oil and gas production areas. Food prices are likely to go up as a result of a pool of labour in the oil and gas industrial area. This should be seen as an opportunity rather than a threat. What advantages are available for the numerous women who find themselves in farming? They need training in farming methods, good farming practices, extension services and credit to undertake the cultivation of food crops and vegetables. Is this not an indirect participation in the oil and gas industry? The high income to be earned by the oil field workers will be transferred to women who are farmers. In this regard, we are arguing that farming should be used as an alternative strategy and that farming must go with best practices and with support from government. What needs to be done is the creation of the Agricultural Development Fund (ADF) with special focus on 
women in farming which is in the pipeline. Over the years several governments and regimes have tried it and the impact did not yield any significant result. With the oil and gas discovery, more attention should focus on pushing resources to women in farming in order to increase their productivity.

One of the experiences that oil and gas producing countries have gone through is the fall in the employment of the commodity sub-sector ${ }^{4}$. The development of this sector is very important for the development of the oil and gas discovery. Women will require financial resources in order to fill this employment gap. This is the time existing women entrepreneurs in rural areas can generate new business ideas, expand their businesses, and benefit from the wages and salaries received by men working in the oil and gas industry.

What alternative livelihood project could be made available for these women in the oil and gas areas? The issue of alternative livelihood projects is not new in Ghana. In the mining areas such as Bogoso, Ayanfuri, Dunkwaw, Obuasi, just to mention a few, several attempts have been made. For example Golden Star Bogoso-Prestea Ltd. (GSBPL), AngloGold Ashanti-Ayanfuri, Gold Fields Ghana Limited, Tarkwa Mine, and Anglo Gold Ashanti Iduapriem have implemented several alternative livelihoods for the people in these areas. The oil and gas mining is not too different from these projects (Temeng and Abew, 2009).

We propose that the establishment of hand-in-hand programme for women who seek to build capacity and promote existing economic activities as well as new ones (Anon, 2007c). The programme should include training in entrepreneurial skills; micro-credit management; animal husbandry and livestock; food processing and value-addition technologies; water, sanitation and personal hygiene; participatory decision-making and problem solving as proposed by Temeng and Abew (2009). For successful implementation of these projects, funds should be made available for target women who exit the training programme. Economic empowerments that will deliberately target women in microcredit financing with minimum bottlenecks is very necessary for alternative livelihood. This will enable them take advantage of the end products of the petrochemical activities.

One of the immediate ALP that can be undertaken is equipping women with skills to produce local fabrics and cosmetics and toiletries. These include batik-tye-and-dye ${ }^{5}$, soap (alata samina) ${ }^{6}$, pomade, and local powder. With financial support from the oil companies, women will be able to earn a living through these activities. It is proposed that since capital requirement is not huge, microfinance will be able finance these activities.

Another ALP that can be identified in the district is coconut oil extraction. This activity is engaged on a very small scale at the moment basically for subsistence consumption. As women claim that they will lose their fish and fishing related activities, there is the need to equip these women with skills that make them produce coconut oil on a larger scale. Microfinance has the potency for empowering women in undertaking such projects. There is therefore the need to support them with micro-credit. In the case of Prestea and Bogoso for instance, a large oil palm plantation (10,000 hectare) was cultivated by Golden Star, the mining company, to employ the people in palm oil processing. The people were given credit assistance as start-up capital for the initial processing. In a similar vein, we propose that the oil companies as a way of discharging their corporate responsibility should cultivate hybrid of coconut plantation for the community for future employment.

\section{Conclusion and recommendations}

Natural resource and oil and gas discovery have not benefited women who in some countries have protested against governments (Jike, 2010). The objective of this paper was to explore the potential effects, possible opportunities and alternative livelihood activities for women in the oil and gas exploration areas in Ghana. In three communities in the Ahanta West District, 240 women were interviewed to find out their perception about the oil and gas discovery in the region. Women perceive that their direct involvement in the oil and gas production will be very limited because it is claimed they do not have the requisite skills and know-how. These downsides of the thoughts of the people continue to raise doubts about the constantly acclaimed benefits of oil and gas discovery.

Within the vulnerability context, the challenges are likely to produce shocks. With existing natural resources in the region, women need livelihood assets including capacity building, finance, physical assets, and social networks in order to be empowered. The government should put proper structures and processes for the optimum use of available resources so that livelihood strategies could be well developed in order to produce outcomes. The expected outcomes should increase income for women, improve their well-being, enhance food security and reduce vulnerability. There is also the need for public-private partnership, constant dialogue with traditional leaders, regular meeting with civil society organization and general education using the media, religious bodies and organized women groups. 
Oil revenue must be well managed in order to benefit Ghanaians in general and women in particular. For this to be achieved, the Oil Revenue Management Bill which is currently in parliament needs to be passed into a law for its quick implementation. Further to this and for sound fiscal management, oil revenue should be accommodated into special account other than the consolidated fund. The substance of this proposition is that, it will ensure optimum use of the revenues and enhance proper accountability. Besides, to ensure active participation of women with the know-how, the Local Content Bill should be passed into law to ensure that employment opportunities and active participation by Ghanaians and especially women are catered for. The Draft Fundamental Petroleum Policy for Ghana, 2008 seem not to have addressed the gender disparity in the petroleum sector with special reference to the oil discovery. In the light of this, there is the need to open up the draft document for further deliberations and conscious efforts should be made to address the gender gaps that seem to be present in the document.

The paper is however not without flaws. The study was limited in scope in terms of target respondents and selected communities. Again, the study focused on just small percentage of women population which might be biased. Since the study was conducted before the actual drilling of the oil, respondents' perception might not reflect the actual situation during post drilling activities. Further study needs to be done to cover all communities and a wider sample including men and the youth some time after the actual production has started.

\section{Acknowledgement}

We are very grateful to Level 300 Bachelor of Social Science students who offer Economics of HIV/AIDS (2010/2011) for the data collection. We also express our sincere thanks to William Godfried Canta and Rita Ofosu-Brefo, both teaching assistants at the Department of Economics, University of Cape Coast for the data entry.

\section{References}

Anon, C. (2007c). Annual Report of Anglo Gold Ashanti, Anglo Gold Ashanti pp 32 - 50.

Daily Graphic, Monday, October 25, 2010: Jubilee Field 95\% ready, pp.3

Darkwah, A. (2010). The Impact of Oil and Gas Discovery and Exploration on Communities with Emphasis on Women. [Online] Available: http://www.g-rap.org/docs/oil_and_gas/netright-akosua_darkwah-2010.pdf

des Clers, S. (2007). Mitigating the Impact of Oil Exploration and Production on Coastal and

Wetland Livelihoods in Central and West Africa, Sustainable Fisheries Livelihood Programme, DFID/FAO/SFLP

Elson, D. \& Pearson, R. (1997). The Subordination of Women and the Internationalization of factory Production', In The Women, Gender and Development Reader, edited by Visvanathan, Nalini, Duggan, Lynn, Nisonoff, Laurie and Wiegersma. Halifax, Canada: Fernwood Publishing Ltd.

Falkinger, J. \& Grossmann, V. (2005). Institutions and Development: The Interaction between Trade Regime and Political System. Journal of Economic Growth 10, 229-270.

Fatusin, A. F., Afolabi, A. \& Adetula, G. A. (2010). The Impacts of Oil and Gas Pollution on Female Gender in Ilaje, Niger Delta Region of Ondo State Nigeria, Journal of Human Ecology, 32(3): 189-196 (2010).

Gabriel, A. O. I. (2004). Women in Niger Delta: Environmental Issues and Challenges in the Third Millennium. [Online] Available: www.jsd-africa.com http://www.20-first.com/1007-0-what-is-happening-with-the-women-in-the-oil-and-gas-industry.html.

Galor, O., O. Moav and D. Vollrath. 2009. "Inequality in Land ownership, the Emergence of Human Capital Promoting Institutions and the Great Divergence" (with) Review of Economic Studies, 76, 143-179.

Ghana Statistical Service, (2008). Report on Ghana living Standards Survey 5. Accra. GSS

Imevbore, A.A.A. \& Adeyemi S.A. (1981). Environmental monitoring in relation to pollution and control of oil pollution. In Proc. Seminar on the petroleum Industry and the Nigerian Environment. 6: pp135-142

Inglehart, R and N. Pippa. (2003). Rising Tide: Gender Equality and Cultural Change Around the World. New York: Cambridge University Press.

Jike, V. T. (2010). Environmental Degradation and the Resurgence of Non-Violent Protest by Women in the Warri Metropolis of Southern Nigeria. Journal of Social Science: 23(3) 207-212.

Odamem, F.S. (n.d). Women in the Oil Industry: Promoting Social and Economic Development in Ghana. Tamale: University for Development Studies. 
Olankunle, F.M. (2010). Women's Response to the Question of Development in the Niger Delta, Nigeria, Journal of Comparative Research in Anthropology and Sociology 1(1), 133-149.

Olusegun, A.O. (2009). Gender, Sustainable Peace, and Development in the Niger Delta Region of Nigeria, Journal of Sustainable Development in Africa, 11(2).

Omorodion, F.I. (2004). The impact of Petroleum Refinery on the Economic Livelihoods of Women in the Niger Delta Region of Nigeria, Journal of Culture and African Women Studies:6.

Rao, A. S \&. Pathak D. S. (1996). Women in Economic Development. New Delhi, India: Creative Books.

Ross, M.L. (2008). Oil, Islam and Women. American Political Science Review: 102(1) 107-123.

Sachs, J. \& Warner, A. (1995). The Curse of Natural Resources. European Economic Review 45: 827-38.

Sherk, S. (2004). A Report on Women in Canada's Oil and Gas Sector. AGRA Earth and Environmental Ltd.

Tadjoeddin, M. Z. (2007). A Future Resource Curse in Indonesia: The Political Economy of Natural Resources, Conflict and Development. Crise Working Paper No. 35.

Temeng, V. A. \& Abew, J. K. (2009. A Review of Alternative Livelihood Projects in Some Mining Communities in Ghana. European Journal of Scientific Research: 35(2) 217-228.

\section{Notes}

Note 1. The local name for Cape Three Points is Akyinkyin

Note 2. In Ghana fishermen do not go to sea on Tuesdays since it is believed that the sea god wakes up on Tuesdays. Rituals for the sea god are performed on this day. Offenders are summoned to appear before the traditional authorities for sanctions. With oil mining it means the sea god will not have rest and this is expected to affect fish catch.

Note 3. These respondents have no economic activities apart from fish mongering, salting and smoking.

Note 4 . The sub-sector of the commodity sector is part of the service sector where transaction of durable and non-durable consumer items take place. During oil and gas discovery labour force in the commodity sub-sector reduces transfer of labour.

Note 5. A local fabric made from calico.

Note 6. This is the name given to local soap in southern Ghana. It is made from local products such as palm oil, maize cobs, plantain peals, palm nut fibre and cocoa pods. It does not require any sophisticated technology to produce. This type of soap sells well on the market because it is less expensive.

Table 1. Population, age and sex distribution

\begin{tabular}{lcccc}
\hline Age group & Male & Female & Total & $\%$ \\
\hline 0-5years & 19,751 & 20,771 & 40,552 & 42.6 \\
15-64years & 23,663 & 26,075 & 49,738 & 52.3 \\
64 or more years & 1,986 & 2,892 & 4,878 & 5.1 \\
\hline Total & $45,400(47.7 \%)$ & $49,738(52,3 \%)$ & 95,168 & 100.0 \\
\hline
\end{tabular}

Source: Ahanta West District Assembly, 2010 
Table 2. Effects of oil and gas exploration

\begin{tabular}{lccc}
\hline Perceived challenge by women & Frequency & $\%$ & Cumulative (\%) \\
\hline Low fish catch & 67 & 27.9 & 27.9 \\
Loss of job & 31 & 12.9 & 40.8 \\
Low level of income & 27 & 11.2 & 52.0 \\
Legal issues against offenders & 24 & 10.0 & 62.0 \\
Loss of farm produce & 23 & 9.6 & 71.6 \\
IIigh cost of living & 22 & 9.2 & 80.8 \\
Unable to fish at all & 15 & 6.2 & 87.0 \\
Bad state of road and heavy vehicles & 12 & 5.0 & 92.0 \\
Environmental degradation/pollution & 8 & 3.3 & 95.3 \\
Harassment by naval officials & 7 & 2.9 & 98.2 \\
Cultural change & 4 & 1.8 & 100.0 \\
\hline Total & 240 & 100.0 & \\
\hline
\end{tabular}

Source: Field survey, 2010.

Table 3. Expected loss of Income from fishing activities

\begin{tabular}{lccc}
\hline Income range (Ghana cedis) & Frequency & $\%$ & Cumulative \% \\
\hline Less than 100 & 69 & 28.0 & 28.9 \\
$101-200$ & 37 & 15.5 & 44.4 \\
$201-500$ & 19 & 7.9 & 52.3 \\
$501-1000$ & 26 & 10.9 & 63.2 \\
More than 1000 & 17 & 7.1 & 70.3 \\
Does not know & 71 & 29.7 & 100.0 \\
\hline Total & $\mathbf{2 3 9}$ & $\mathbf{1 0 0 . 0}$ & \\
\hline
\end{tabular}

\section{Statistics}

Maximum income loss

More than Ghana cedis 1000

Mean loss of income

Between Ghana cedis 201-500

Minimum income loss

less than Ghana cedis 100

Source: Field survey, 2010 
Table 4. Source of Livelihood (other than fishing activities)

\begin{tabular}{lccc}
\hline Activity & Frequency & $\%$ & Cumulative $\%$ \\
\hline Farming & 165 & 68.8 & \\
None $^{3}$ & 24 & 10.0 & 73.8 \\
Petty trading & 16 & 6.7 & 83.8 \\
Artisanal work & 15 & 6.2 & 90.5 \\
Food processing & 5 & 2.1 & 96.7 \\
Galamsay & 3 & 1.2 & 98.8 \\
\hline Total & $\mathbf{2 4 0}$ & $\mathbf{1 0 0 . 0}$ & 100.0 \\
\hline
\end{tabular}

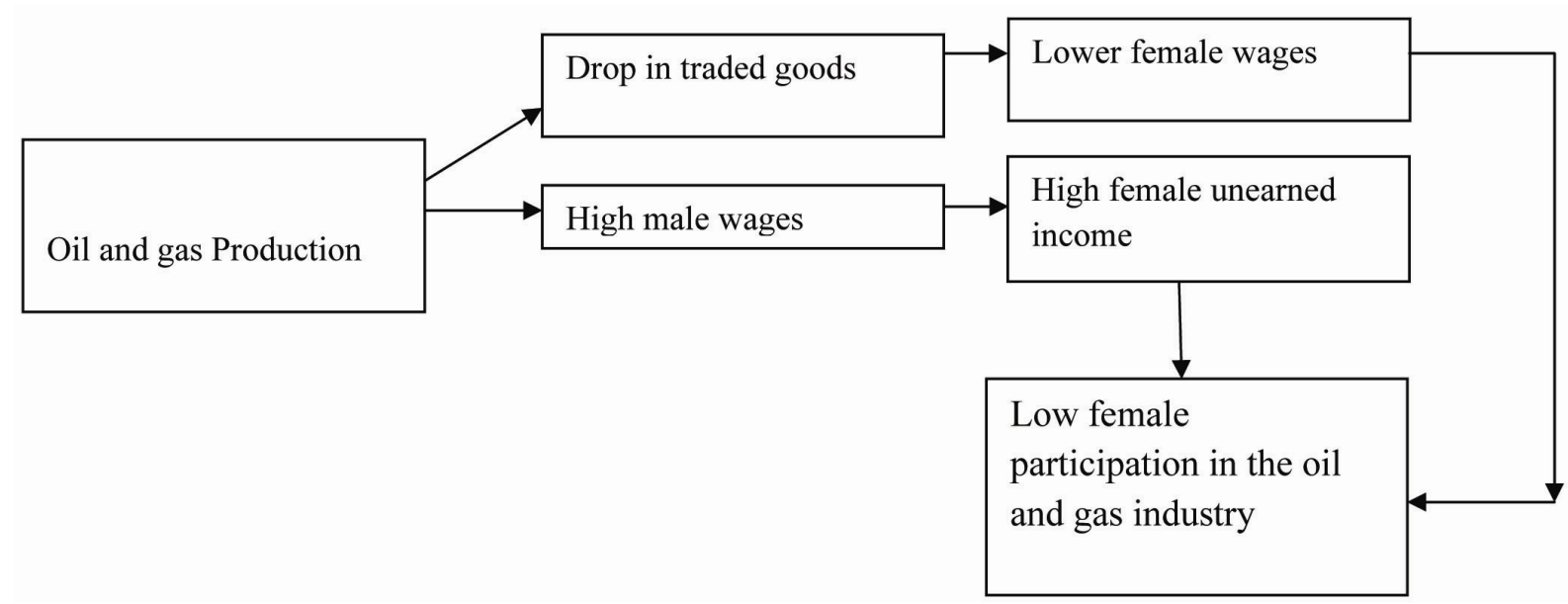

Figure 1. Impact of oil and gas production on women

Adapted from Ross (2008) 